\title{
BIOCHEMICAL SCREENING OF DIABETIC NEPHROPATHY
}

\author{
Vivek Sinha1 , Arun Kumar ${ }^{2}$ \\ ${ }_{1}^{1}$ Assistant Professor, Department of Biochemistry, Saraswathi Institute of Medical Sciences, Anwarpur, Hapur, Uttar Pradesh. \\ ${ }^{2}$ Demonstrator, Department of Biochemistry, Saraswathi Institute of Medical Sciences, Anwarpur, Hapur, Uttar Pradesh.
}

\begin{abstract}
Diabetic nephropathy is a clinical syndrome characterized by the following- Persistent albuminuria ( $>300 \mathrm{mg} / \mathrm{d}$ or $>200 \mu \mathrm{g} / \mathrm{min})$, that is confirmed on at least 2 occasions 3-6 months apart diabetic, progressive decline in the Glomerular Filtration Rate (GFR), elevated arterial blood pressure. The earliest biochemical criteria for the diagnosis of diabetic nephropathy is the presence of microalbumin in the urine, which if left untreated will eventually lead to End-Stage Renal Disease (ESRD). Micro-albuminuria refers to the excretion of albumin in the urine at a rate that exceeds normal limits. The current study was conducted to establish the prevalence of micro-albuminuria in a sequential sample of diabetic patients attending hospital and OPD Clinic to determine its relationship with known and putative risk factors to identify micro- and normo-albuminuric patients in their sample for subsequent comparison in different age, sex, weight and creatinine clearance of the micro- and normo-albuminuric patients. This cross-sectional analytical study was conducted in one hundred patients at Saraswathi Institute of Medical Sciences, Anwarpur, Hapur, U. P. Patients having diabetes mellitus in different age group ranging from 30 to 70 years were selected. Data was analysed by SPSS software. Microalbuminuria was observed in 35\% in patients with type 2 diabetes mellitus. It was observed that $65 \%$ patients were free from any type of albuminuria. Also micro-albuminuria was present in $10 \%$ of the patients less than 50 yrs. of age, while $15 \%$ of the patients more than $50 \mathrm{yrs}$. of age were having micro-albuminuria. There was a statistically significant correlation of micro-albuminuria with duration of diabetes. Incidence of micro-albuminuria increases with age as well as increased duration of diabetes mellitus. Our study shows that only $5 \%$ patients developed macro-albuminuria. Glycosylated haemoglobin and fasting plasma glucose was significantly raised among all these patients.
\end{abstract}

\section{KEYWORDS}

Diabetic Nephropathy, Micro-Albuminuria, Diabetes Mellitus.

HOW TO CITE THIS ARTICLE: Sinha V, Kumar A. Biochemical screening of diabetic nephropathy. J. Evolution Med. Dent. Sci. 2016; 5(9):381-385, DOI: 10.14260/jemds/2016/87

\section{INTRODUCTION}

Diabetic nephropathy is a clinical syndrome characterized by the following- Persistent albuminuria $(>300 \mathrm{mg} /$ day or $>200 \mu \mathrm{g} / \mathrm{min}$ ) that is confirmed on at least 2 occasions 3-6 months apart diabetic, progressive decline in the Glomerular Filtration Rate (GFR), elevated arterial blood pressure. Up to $30 \%$ of people with newly diagnosed type-2 diabetes will already have abnormally high urine albumin levels. About $75 \%$ of these people will have micro-albuminuria and about $25 \%$ have overt diabetic nephropathy (Delcourt C, et al. ${ }^{1}$ and Krolewski AS, et al. ${ }^{2}$ ). Diabetes nephropathy is now the single most common cause of ESRD in worldwide. ${ }^{3}$ Diabetic nephropathy presents in its earliest stage with low levels of albumin (Micro-albuminuria) in the urine (Gall MA, et al.). ${ }^{4}$ Clinically diabetic nephropathy is characterized by a progressive increase in proteinuria and decline in GFR, hypertension and high risk of cardiovascular morbidity and mortality. In diabetic patients with proteinuria the relative mortality is about 40 times higher than in diabetes without proteinuria. It is now established that in both type 1 and type 2 DM, urinary excretion of small amounts of albumin (Microalbuminuria) is predictive of morbidity and mortality due to renal complication and cardiovascular disease. ${ }^{5-7}$

Financial or Other, Competing Interest: None

Submission 10-12-2015, Peer Review 09-01-2016,

Acceptance 20-01-2016, Published 30-01-2016.

Corresponding Author:

Arun Kumar,

Arjun Colony, Ward No. 4, Gohad, Dist.,

Bhind-477116, Madhya Pradesh.

E-mail: kumararun465@gmail.com

DOI: $10.14260 /$ jemds/2016/87
Micro-albuminuria is now recognized as an independent risk factor, even in the absence of diabetes. The determination of micro-albuminuria in diabetes mellitus is important, as it is the earliest indicator of diabetic nephropathy, which if left untreated will eventually lead to end stage renal disease. Micro-albuminuria is best determined on a $24 \mathrm{hr}$. urine sample.

For convenience a random sample can also be used and the test done with the micral test strip (Leong SO, et al. ${ }^{8}$ and $\mathrm{Ng}$ WY, et al. ${ }^{9}$ ) Main objective of our present study is to detect the onset of albuminuria among diabetic patients and the effect of hyperglycemia in causing this at an early stage, so that the renal complications can be prevented.

\section{MATERIALS AND METHODS}

Present study was carried out in the Department of Biochemistry, Saraswathi Institute of Medical Sciences, Anwarpur, Hapur, U.P. on the clinically diagnosed cases of diabetes mellitus having signs and symptoms of diabetic nephropathy. Estimation of micro-albuminuria was done in these patients, as it is earliest indicator of diabetic nephropathy. The study period was from November 2015 to December 2015. The patients were either on diet control or taking drugs. These cases were selected from the outdoor and indoor departments; permission from concerned authorities was dully obtained.

In our study 100 cases of known diabetes mellitus (The criteria of the diagnosis of diabetes mellitus were of patients having the fasting blood glucose levels more than $126 \mathrm{mg} / \mathrm{dl}$ ) was selected from different age group ranging from 30 to 70 years. Their consent was taken. All the cases in the study group were clinically of Non-Insulin Dependent Diabetes Mellitus, type-2 (NIDDM). 
The diagnosis of diabetic nephropathy was made on the basis of history, physical examination and the laboratory investigations of urine and blood. The earliest biochemical criteria for the diagnosis of diabetic nephropathy is the presence of micro-albumin in the urine, which if left untreated will eventually lead to end stage renal disease. Other biochemical parameters are estimation of BUN and serum creatinine and $\mathrm{HbA} 1 \mathrm{c}$.

The blood glucose level was estimated by glucose oxidase peroxidase (GOD/POD) Accurex Biomedical Pvt. Ltd. and glycosylated hemoglobin by ion exchange resin separation method. The glycosylated hemoglobin (HbA1c) test was done by test kit, (Manufactured by ERBA diagnostics Mannheim GmbH Germany and marketed by Transasia Pvt. Ltd.) Microalbumin was estimated in all samples by the kit supplied by BioSystems S.A. Costa Brava 30, Barcelona, Spain. Serum urea and creatinine were estimated by kit supplied by span diagnostics; $2 \mathrm{ml}$ of blood was withdrawn from the selected site (Antecubital vein) and transferred to EDTA vial for the estimation of HbA1c levels. The blood was mixed properly with the anticoagulant by gentle shaking. For the estimation of blood glucose, $2 \mathrm{ml}$ of blood was withdrawn from the antecubital vein and transferred to sodium fluoride-potassium oxalate vials.

Micro-albuminuria has been defined using different units of measurements. According to Gento-Montecatini, Microalbuminuria is present when the Urinary Albumin Excretion Rate (UAER) in 24-hour urine or short time collected urine during daytime is in the range of $30-300 \mathrm{mg} / 24 \mathrm{hr}$. (20-200 microgram $/ \mathrm{min}$ ), which is equivalent to 0.46 to 4.6 micromol/24 hr. urine sample should be collected when the patient is at rest and his diabetes is under average clinical control. No measurements should be made in patients with ketosis or poor control until proper control is established. If excretion is lower than $20 \mathrm{microgram} / \mathrm{min}$, the patient is considered to have normo-albuminuria and if excretion is higher than $200 \mathrm{microgram} / \mathrm{min}$, he is considered to have Macro-albuminuria or clinical proteinuria. Micro-albuminuria should be present in at least two or three urine samples collected over a period of several months.9,10 the data for biochemical analysis are expressed as Mean S.E.M. the entire data was analysed by using the statistical package program SPSS.

\section{OBSERVATIONS}

Below table shows that $35 \%$ of the total patients develop albuminuria and $65 \%$ patients were free from any type of albuminuria.

\begin{tabular}{|c|c|}
\hline Type of Patients Studied & Percentage \\
\hline Patients with micro-albuminuria & 35 \\
\hline Patients without micro-albuminuria & 65 \\
\hline \multicolumn{2}{|c|}{ Table 1: Diabetic patients with or without } \\
micro-albuminuria \\
\hline
\end{tabular}

\begin{tabular}{|c|c|c|}
\hline $\begin{array}{c}\text { Age of } \\
\text { patients (In } \\
\text { years) }\end{array}$ & $\begin{array}{c}\text { Number of } \\
\text { patients with } \\
\text { micro- } \\
\text { albuminuria }\end{array}$ & $\begin{array}{c}\text { Number of } \\
\text { patients with } \\
\text { frank proteinuria }\end{array}$ \\
\hline $\begin{array}{c}\text { Less than } 50 \\
\text { years }\end{array}$ & 10 & 5 \\
\hline $\begin{array}{c}\text { More than } 50 \\
\text { years }\end{array}$ & 15 & 5 \\
\hline
\end{tabular}

Table 2: Age wise distribution of diabetic patients with micro-albuminuria and frank proteinuria

\begin{tabular}{|c|c|c|c|c|}
\hline Serial No. & $\begin{array}{c}\text { Age } \\
\text { (in years) }\end{array}$ & $\begin{array}{l}\text { Micro-albuminuria } \\
\quad \text { (in mg /day) }\end{array}$ & $\begin{array}{c}\text { Fasting plasma } \\
\text { glucose } \\
\text { (in mg / dl) } \\
\end{array}$ & $\begin{array}{l}\text { HbA1c } \\
\text { (in \%) }\end{array}$ \\
\hline 1 & 32 & 44 & 159 & 9.3 \\
\hline 2 & 38 & 101 & 152 & 7.8 \\
\hline 3 & 44 & 250 & 198 & 9.6 \\
\hline 4 & 48 & 72 & 146 & 7.9 \\
\hline 5 & 32 & 280 & 129 & 9.8 \\
\hline 6 & 38 & 95 & 130 & 9.8 \\
\hline 7 & 47 & 52 & 203 & 8.6 \\
\hline 8 & 35 & 160 & 196 & 9.3 \\
\hline 9 & 36 & 96 & 160 & 8.7 \\
\hline 10 & 41 & 156 & 165 & 9.3 \\
\hline Mean \pm S.E.M & & $131 \pm 26.46$ & $163 \pm 8.55$ & $9.01 \pm 0.23$ \\
\hline
\end{tabular}

The data present in the above table shows that micro-albuminuria was directly correlated with fasting plasma glucose and HbA1c among the person who is less than 50 years of age. There is an increase in the micro-albumin with increase Hba1c and fasting plasma glucose. It also appears that the total number of patients with micro-albuminuria were only 10 out of 100 . That indicates only $10 \%$ patient's developed micro-albuminuria, who was less than 50 years. 


\begin{tabular}{|c|c|c|c|c|}
\hline Serial No. & $\begin{array}{c}\text { Age } \\
\text { (In years) }\end{array}$ & $\begin{array}{l}\text { Micro-albuminuria } \\
\text { (in mg /day) }\end{array}$ & $\begin{array}{l}\text { Fasting Plasma Glucose } \\
\text { (In mg/dl) }\end{array}$ & $\begin{array}{l}\text { HbA1c } \\
\text { (In \%) }\end{array}$ \\
\hline 1 & 70 & 185 & 170 & 7.7 \\
\hline 2 & 60 & 234 & 134 & 10.5 \\
\hline 3 & 51 & 280 & 195 & 8.2 \\
\hline 4 & 58 & 232 & 132 & 10.5 \\
\hline 5 & 62 & 234 & 220 & 7.9 \\
\hline 6 & 67 & 52 & 129 & 8.9 \\
\hline 7 & 81 & 79 & 165 & 8.8 \\
\hline 8 & 70 & 96 & 182 & 7.8 \\
\hline 9 & 71 & 272 & 156 & 8.0 \\
\hline 10 & 62 & 256 & 220 & 8.2 \\
\hline 11 & 60 & 108 & 198 & 8.0 \\
\hline 12 & 77 & 208 & 152 & 9.2 \\
\hline 13 & 60 & 48 & 145 & 8.1 \\
\hline 14 & 75 & 170 & 139 & 9.6 \\
\hline 15 & 78 & 92 & 160 & 9.2 \\
\hline Mean \pm S.E.M. & & $169.73 \pm 21.37$ & $166.46 \pm 7.91$ & $8.706 \pm 24$ \\
\hline \multicolumn{5}{|c|}{$\begin{array}{c}\text { Table 4: Level of fasting plasma glucose, micro-albuminuria and HbA1c among } \\
\text { diabetic patients more than } 50 \text { years of age }\end{array}$} \\
\hline
\end{tabular}

The data available in the above table shows that there is an increase in urinary micro-albumin with increase in HbA1c and fasting plasma glucose in the patients of more than 50 years of age. It also appears that total no. of patients with micro-albuminuria were only 15 out of 100 . That indicates only $15 \%$ of patients developed micro-albuminuria who were more than 50 years of age.

\begin{tabular}{|c|c|c|c|c|}
\hline Serial No. & Age (In years) & $\begin{array}{l}\text { Micro-albuminuria } \\
\text { (In mg/day) }\end{array}$ & $\begin{array}{l}\text { Serum Urea } \\
\text { (In mg/dl) }\end{array}$ & $\begin{array}{l}\text { Serum Creatinine } \\
\text { (In } \mathrm{mg} / \mathrm{dl} \text { ) }\end{array}$ \\
\hline 1 & 30 & 50 & 31 & 09 \\
\hline 2 & 40 & 103 & 38 & 1.1 \\
\hline 3 & 45 & 250 & 22 & 1.2 \\
\hline 4 & 49 & 72 & 35 & 0.8 \\
\hline 5 & 32 & 290 & 33 & 1.3 \\
\hline 6 & 38 & 85 & 20 & 0.7 \\
\hline 7 & 47 & 52 & 24 & 0.7 \\
\hline 8 & 35 & 170 & 38 & 0.8 \\
\hline 9 & 36 & 86 & 38 & 0.4 \\
\hline 10 & 41 & 156 & 40 & 0.8 \\
\hline Mean \pm S.E.M & & $131.40 \pm 2.46$ & $31.90 \pm 2.27$ & $0.88 \pm 0.084$ \\
\hline
\end{tabular}

Above table shows that the group of patients of 50 years of age who developed micro-albuminuria (131.40 \pm 26.46$)$ did not have increased level of serum urea and creatinine. The urea and creatinine levels were in the normal range.

\begin{tabular}{|c|c|c|c|c|}
\hline Serial No. & Age (In years) & $\begin{array}{l}\text { Micro-albuminuria } \\
\text { (In mg/day) }\end{array}$ & $\begin{array}{l}\text { Serum Urea } \\
\text { (In } \mathrm{mg} / \mathrm{dl} \text { ) }\end{array}$ & $\begin{array}{l}\text { Serum Creatinine } \\
\text { (In mg/dl) }\end{array}$ \\
\hline 1 & 70 & 188 & 30 & 0.7 \\
\hline 2 & 60 & 231 & 27 & 0.8 \\
\hline 3 & 51 & 280 & 34 & 0.9 \\
\hline 4 & 58 & 232 & 29 & 0.8 \\
\hline 5 & 62 & 234 & 22 & 0.9 \\
\hline 6 & 67 & 52 & 24 & 0.9 \\
\hline 7 & 81 & 79 & 30 & 1.1 \\
\hline 8 & 70 & 96 & 40 & 1.2 \\
\hline 9 & 71 & 272 & 24 & 0.9 \\
\hline 10 & 62 & 256 & 23 & 0.9 \\
\hline 11 & 60 & 108 & 39 & 1.0 \\
\hline 12 & 77 & 208 & 32 & 0.8 \\
\hline 13 & 60 & 48 & 32 & 1.1 \\
\hline 14 & 75 & 170 & 30 & 0.8 \\
\hline 15 & 78 & 92 & 24 & 1.2 \\
\hline Mean \pm S.E.M & & $169.73 \pm 21.37$ & $29.3 \pm 1.42$ & $0.93 \pm 0.039$ \\
\hline \multicolumn{5}{|c|}{$\begin{array}{c}\text { Table 6: Level of micro-albuminuria, serum urea and serum creatinine } \\
\text { among diabetic patients more than } 50 \text { years of age }\end{array}$} \\
\hline
\end{tabular}

Above table shows that group of patients above 50 years of age who developed micro-albuminuria (169.73 \pm 21.37$)$ did not have increased serum urea and creatinine levels. There serum urea and creatinine levels were in normal range. 


\begin{tabular}{|c|c|c|c|c|}
\hline Serial No. & Age in Years & $\begin{array}{c}\text { Total Urinary Protein } \\
\text { (In mg/day) }\end{array}$ & HbA1 (In \%) & $\begin{array}{c}\text { Fasting Plasma Glucose } \\
\text { (In mg/dl) }\end{array}$ \\
\hline 1 & 49 & 1200 & 11 & 168 \\
\hline 2 & 48 & 3200 & 32.2 & 133 \\
\hline 3 & 39 & 2900 & 10.2 & 194 \\
\hline 4 & 42 & 2600 & 12.8 & 178 \\
\hline 5 & 41 & 2200 & 11.2 & $\mathbf{1 6 5 \pm 1 0 . 0 4}$ \\
\hline Mean+S.E.M & \multicolumn{2}{|c|}{$\begin{array}{c}\text { Table 7: Level of frank proteinuria, HbA1c and fasting } \\
\text { plasma glucose among diabetic patients less than 50 years of age }\end{array}$} \\
\hline
\end{tabular}

Above table shows that only $5 \%$ of the patients developed macro-albuminuria, HbA1c as well as fasting plasma glucose was significantly raised among all these patients. All these patients belonged to less than 50 years of age group.

\begin{tabular}{|c|c|c|c|c|}
\hline Serial No. & Age in Years & $\begin{array}{c}\text { Total Urinary Protein } \\
\text { (In mg/day) }\end{array}$ & HbA1 (In \%) & $\begin{array}{c}\text { Fasting Plasma Glucose } \\
\text { (In mg/dl) }\end{array}$ \\
\hline 1 & 60 & 2740 & 11.1 & 170 \\
\hline 2 & 70 & 2400 & 9.8 & 194 \\
\hline 3 & 69 & 1560 & 9.3 & 210 \\
\hline 4 & 52 & 2580 & 12.6 & 155 \\
\hline 5 & 52 & 3300 & 12.2 & 178 \\
\hline Mean \pm S.E.M & & $2516 \pm 285$ & $11.0 \pm 0.64$ & $181.40 \pm 9.29$ \\
\hline
\end{tabular}

Above table shows that only $5 \%$ of the patients developed macro-albuminuria, HbA1c as well as fasting plasma glucose was significantly raised among all these patients. All these patients belonged to more than 50 years of age group.

\section{DISCUSSION}

In this study, it was observed that $35 \%$ of total patients developed and $65 \%$ patients were free from any type of albuminuria. Also micro-albuminuria was present in $10 \%$ of the patients less than 50 yrs. of age, while $15 \%$ of the patients more than 50 yrs. of age were having micro-albuminuria. Various epidemiological and cross-sectional studies have reported marked variation in the prevalence of microalbuminuria. ${ }^{10-13}$ Gupta et al. reported a prevalence of $19.7 \%$ from a Tertiary Hospital in Vellore. ${ }^{14}$ Vijay et al. reported that $15.7 \%$ had proteinuria among 600 type-2 diabetic patients studied at a Diabetic Centre in Chennai City. 15 The variation in the prevalence can be attributed to factors such as difference in populations, method of urine collection, etc.

Our study also shows that there is association between albuminuria and age of the patients, level of HbA1c and levels of serum urea and creatinine. Gupta et al. ${ }^{14}$ reported HbA1c to be associated with micro-albuminuria. John et al. ${ }^{16}$ reported male sex, older age, longer duration of diabetes, poor glycemic control and raised blood pressure as risk factors of microalbuminuria, Vijay et al. ${ }^{15}$ reported duration of diabetes, systolic and diastolic blood pressure, age of the patients and serum creatinine to be associated with proteinuria. Age was reported as one of the risk factors in the Wiscosin study. ${ }^{17}$ in a Danish population study and in Pima Indians. ${ }^{18}$ Early stage of Diabetic Nephropathy (DN) is characterized by a small increase in Urinary Albumin Excretion (UAE), also called micro-albuminuria or incipient DN. More advanced disease is defined by the presence of macro-albuminuria or proteinuria. The latter is classically named overt DN. Hyperglycaemia is a significant risk factor for the development of microalbuminuria in diabetes mellitus (Ravid M, et al). ${ }^{19}$ Proteinuria of more than $2 \mathrm{gm} / 24 \mathrm{hr}$. is associated with a greater risk of ESRD (Ruggeneti P, et al. ${ }^{20}$ and Remuzzi G, et al. ${ }^{21}$ ).

\section{CONCLUSION}

During our study we observe that the incidence of diabetic nephropathy increases as the age progresses. The incidence of diabetic nephropathy was more seen in patients above 50 years of age. It was also observed in our study that the normal subjects, in which the blood sugar (FBS and PPBS), HbA1c was in normal range, micro-albuminuria was not observed significantly. There was an increase in micro-albumin with the increase in $\mathrm{HbA1c}$ and fasting plasma glucose.

\section{REFERENCES}

1. Delcourt C, Vauzelle-Kervroedan F, Cathelineau G, et al. Low prevalence of long-term complications in noninsulin dependent diabetes mellitus in France: a multicenter study. Journal of diabetes and its complication. Mar-Apr 1998;12(2):88-95.

2. Krolewaski AS, Laffel LMB, Krolewaski M, et al. Glycosylated haemoglobin and the risk of microalbuminuria in patients with insulin dependent diabetes mellitus. N Eng J Med 1995;332:1251-1255.

3. Cordonniar D, Bayle F, Benhamou PY, et al. Future trends of management of renal failure in diabetics. Kidney Int 1993;43:8-13.

4. Gall MA, Neilsen FS, Schmidt UM, et al. The course of kidney function in type-2 (Non-insulin dependent) diabetic patients with diabetic nephropathy. Diabetologia 1993;36:1071-1078.

5. Albert KGMM. Problems related to definition and epidemiology of type 2 DM. Diabetologia 1993;36:948984.

6. Mogensen CE, Chachati A, Christensen CK, et al. Microalbuminuria: an early marker of renal involvement in diabetes. Uremia Invest 1985-1986;9:85-95.

7. Mogensen CE. Micro-albuminuria as a predictor of clinical diabetic nephropathy. Kidney Int 1987;3:673689.

8. Leong SO, Lui KF, Ng WY, et al. The use of semiquantitative urine test strip (Micral) for microalbuminuria screening in patients with diabetes mellitus. Singapore Med Jour 1998;39(3):101-3. 
9. Ng WY, Lui KF, Thai AC. Evaluation of a rapid screening test for micro-albuminuria with a spot measurement of urine albumin-creatinine ratio. Ann Acad Med Singapore 2000;29:62-5.

10. Mogensen CE, Neldam S, Tikkanen I, et al. Randomised controlled trial of dual blockage of renin-angiotensin system in patients with hypertension, microalbuminuria and non-insulin dependent diabetes. The candesartan and lisinopril micro-albuminuria (CALM) study. BMJ 2000;321(7274):1440-1444.

11. Christensen PK, Gall MA, Parving HH. Course of glomerular filtration rate in albuminuric type-2 diabetic patients with or without diabetic glomerulopathy. Diabetes care 2000;23 (Suppl 2): B14-B20.

12. Klein R, Klein BEK, Moss SE. Prevalence of microalbuminuria in older-onset diabetes. Diabetes care 1993;16:1325-1329.

13. Allawi J, Rao PV, Gillbert R, et al. Micro-albuminuria in non-insulin dependent diabetes: its prevalence in Indian compared with Europid patients. BMJ 1988;296:462464.

14. Gupta DK, Verma LK, Khosla PK, et al. The prevalence of micro-albuminuria in diabetes: a study from North India. Diabetes Res Clin Pract. 1991;12:125-8.

15. Vijay V, Snehalatha C, Ramchandran A, et al. Prevalence of proteinuria in non-insulin dependent diabetes. J Assoc Physicians India 1994;42:792-4.
16. John L, Rao PS, Kanagasabapathy AS. Prevalence of diabetic nephropathy in non-insulin dependent diabetics. Ind Jour Med Res 1991;94:24-9.

17. Schmitz A, Vaeth M. Micro-albuminuria: a major risk factor in non-insulin dependent diabetes: a 10-year follow-up study of 503 patients. Diabet Med 1987;5:12634.

18. Nelson RG, Kunzelman CL, Pettit DJ, et al. Albuminuria in type-2 (non-insulin dependent) diabetes mellitus and impaired glucose tolerance in Pima Indians. Diabetologia 1989;32:870-876.

19. Ravid M, Lang $R$, Rachmani $R$, et al. Long term renoprotective effect of angiotensin converting enzyme inhibition in non-insulin dependent diabetes mellitus. A 7-year follow-up study. Arch Intern Med 1996; Feb 12,156(3):286-289.

20. Ruggenenti P, Gambara V, Perna A, et al. The nephropathy of non-insulin dependent diabetes: predictors of outcome relative to diverse patterns of renal injury. J Am Soc Nephrol 1998;9(12):2336-43.

21. Bertani T, Remuzzi G. Is glomerulosclerosis a consequence of altered glomerular permeability to macromolecules? Kidney Int 1990;38:384-394. 